\section{The microwave irradiation effect on the floatability of mixed sulphide/oxide copper ores}

Rudarsko-geološko-naftni zbornik

(The Mining-Geology-Petroleum Engineering Bulletin) UDC: $622: 669$

DOI: 10.17794/rgn.2021.4.10

Professional paper

\author{
Ataallah Bahrami'; Sajjad Chehreghani'; Fatemeh Kazemi'; Hamid Kazemi'; \\ Abdollah Forughirad'; Behnam Golizadeh' \\ ${ }^{1}$ Department of Mining Engineering, Faculty of Engineering, Urmia University - Iran. \\ ${ }^{2}$ Faculty of Engineering - University of Kashan - Iran.
}

\begin{abstract}
Pre-treatment of copper sulphide and oxide ores using microwave radiation causes a difference in their floatability through change in the surface properties of the minerals. The aim of this study is to investigate the behaviour of Sungun porphyry copper ore under the influence of microwave radiation. In this regard, the feed sample of Sungun copper flotation circuit has been subjected to microwave irradiation for o-120 s and a radiation power of o-6oo W. The prepared samples were then subjected to flotation experiments. According to the results, the grade of sulphide and oxide Cu minerals, as well as the grade of Fe, increased by microwave irradiation in all experiments compared to the non-irradiated samples. At the same time, recovery rate has a reversed trend and decreased in all cases. Variations in the recovery rates of copper oxides and sulphides due to microwave irradiation are different. Increasing the power of irradiation resulted in a greater reduction in the recovery of copper oxides than of sulphides. On the other hand, increasing the power of microwave irradiation reduced the amount of iron recovery in the copper concentrate and with an increase in the duration of microwave irradiation, the reduction of iron recovery values is even more pronounced. Changes in the power and duration of microwave radiation have not had a significant effect on variations in oxide copper grade in flotation tailings. While the grade of sulphides in tailing is affected by the parameters of microwave irradiation and with an increase in power and duration of microwave irradiation, the grade of copper in tailing increases.
\end{abstract}

\title{
Keywords:
}

microwave; flotation; copper oxides and sulphides; iron; pre-treatment

\section{Introduction}

Microwave energy is non-ionized electromagnetic radiation with a frequency in the range of $300 \mathrm{MHz}-300$ $\mathrm{GHz}$ and a wavelength between $300-1 \mathrm{~mm}$. Materials are heated in a microwave field due to the friction created inside the network. The power of the heating caused by the microwave depends on the nature of the molecules in the network, and heating can be done selectively. Therefore, the unique features of microwave heating, such as short operating time, direct and selective heating are the main motives for its application in the field of mineral processing. The use of microwaves in the mining and mineral processing industries began in the 1970s (Kingman et al., 2004; Batchelor et al., 2016; Hassanzadeh, 2017; Batchelor et al., 2017; Gholami et al., 2019a). Microwave irradiation has been used as a pretreatment process for comminution, leaching, flotation and gravity separation of various minerals (Can and Bayraktar, 2007; Batchelor et al., 2016; Marion et al.,

Corresponding author: Sajjad Chehreghani

s.chehreghani@urmia.ac.ir
2016; Batchelor et al., 2017). Studies in this field have focused more on the effect of microwaves on the grindability and breakage of minerals and thus reducing the energy consumption in the comminution process.

Since each mineral has a different value of specific heat capacity, their rate of heat absorption varies when exposed to microwave radiation; this process causes changes in the surface properties of minerals (Kaya, 2010; Gholami et al., 2019b). Studies on surface properties have shown that microwaves have different effects on the surface properties of different minerals (Da-Silva et al., 2018; Da-Silva and Waters, 2018). Microwave irradiation has caused changes in important flotation factors, such as surface charge, specific surface area, porosity and surface energy. Oxidation of sulphide minerals in the presence of oxygen and water is a natural process, which affects the mechanism of collector adsorption on the surface of sulphide minerals and disrupts it (Quast, 2012; Joseph-Soly et al., 2015; Quast, 2016). Microwave irradiation on the surface of sulphide minerals increases their surface oxidation rate (Henda et al., 2005; Can and Bayraktar, 2007). For example, irradiation of these waves on the surface of copper sulphide minerals, 


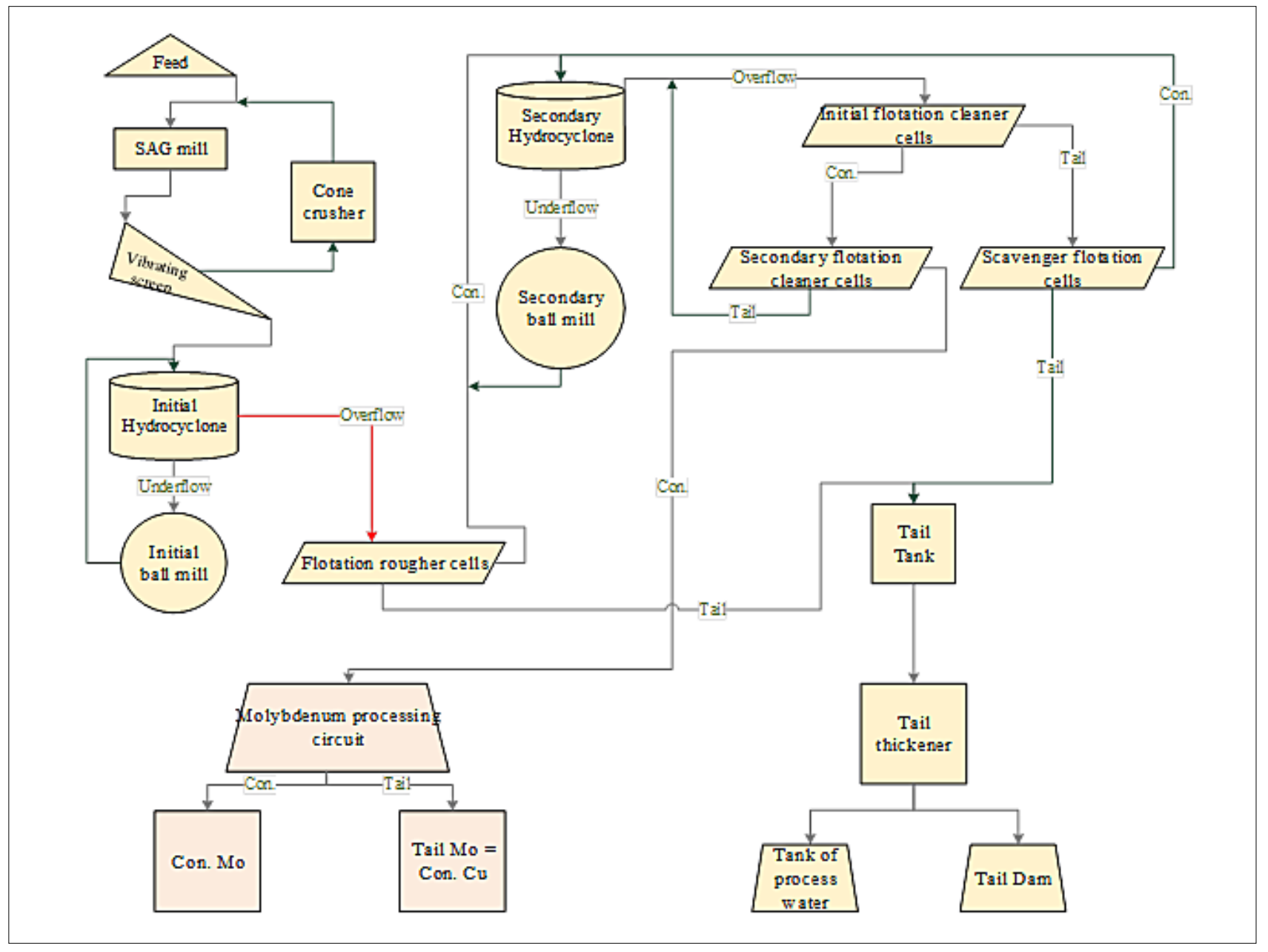

Figure 1: Flowsheet of copper-molybdenum concentration process in Sungun copper plant (Abdollahi, 2019)

including chalcopyrite, reduces the recovery of chalcopyrite, and as radiation power increases, the amount of this decrease is greater. Due to the formation of oxides, hydroxides and oxyhydroxides on the surface, the mineral becomes hydrophilic and its recovery is reduced (Gholami et al., 2020). Studies have shown that microwave radiation causes the zeta potential value of chalcopyrite to change to more negative values (Da-Silva and Waters, 2018); also, the roughness of chalcopyrite surface increases with the effect of a microwave. Therefore, more chemicals are needed to float the particles of this mineral (Gholami et al., 2020). Due to this property, microwaves can be used to differentiate the surface properties of minerals and thus separate them during the flotation process.

Microwave pre-treatment has been considered by a number of researchers to increase the floatability of oxide and sulphide minerals. Studies by Kingman et al. (2000) on Palabora copper sulfide ore show that the floatability of ore is reduced after microwave irradiation in the presence of oxygen, even at low irradiation times. In the presence of nitrogen, the recovery increases at low irradiation times (10 and 30 seconds) and decreases with increasing irradiation time. This is due to the oxidation of the mineral surface by microwave radiation in the presence of oxygen. Studies by Worster et al. (2001) on Neves Corvo copper ore shows that no change in ore flotation recovery was observed after microwave irradiation for 90 seconds while the working index decreased by $15 \%$. Studies by Orumwense and Negeri (2004) on sulphide ores containing pyrite, chalcopyrite, galena, and sphalerite show that copper recovery is intensively reduced after microwave irradiation over long periods of time. Kaya (2010) studied the effect of a microwave on the flotation of two types of copper sulphide ores with different mineralogy. He observed that the recovery for both types of ore is the same as microwave irradiation at low temperatures and without irradiation, but with an increase in microwave irradiation temperature, the recovery decreases due to the surface oxidation of the minerals. In addition, the type of minerals in the ore also affects the heat and flotation recovery properties, so that the rate of recovery reduction after microwave irradiation is different in the two types of ore.

The feed of flotation cells of copper sulphide processing plants contains various types of copper sulphide minerals and smaller amounts of copper oxides, as well as associated gangue minerals. Due to the above men- 


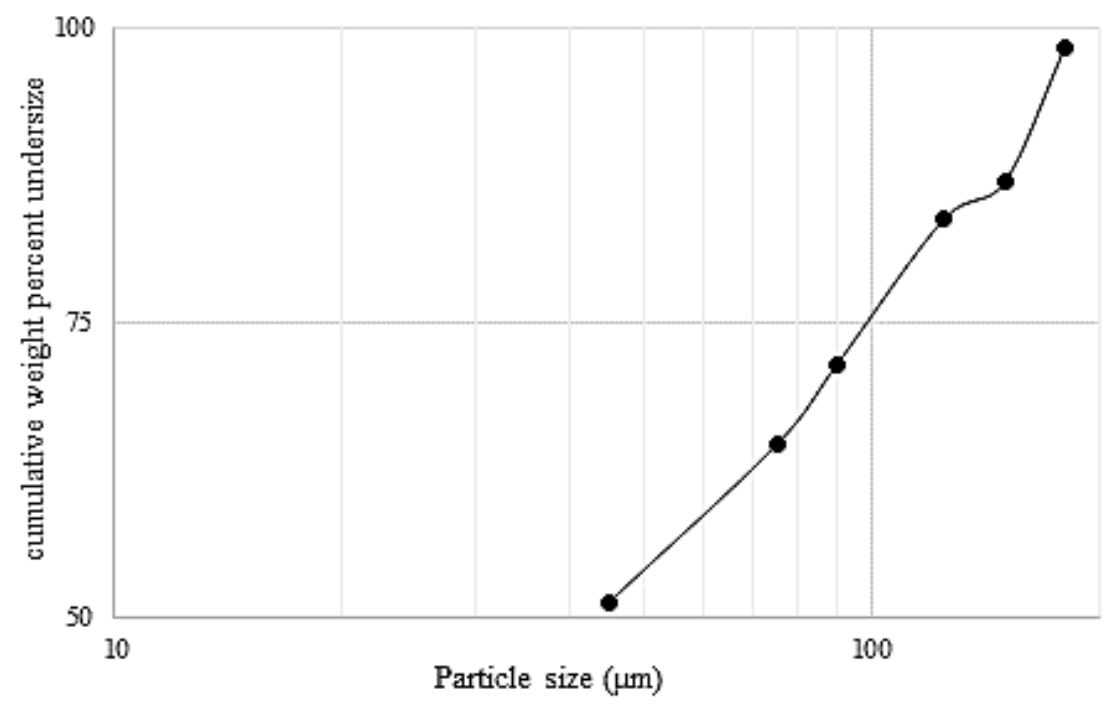

Figure 2: Sieve analysis of Sungun copper flotation circuit feed

tioned subjects, different minerals have different behaviours against microwave radiation and therefore, there will be differences in their floatability. The aim of this study is to investigate the effect of microwaves on the grade and recovery of flotation of Sungun (located in East Azerbaijan province of Iran) copper sulphide ore. It is worth mentioning that Sungun copper porphyry deposit contains sulphide minerals including pyrite, molybdenite, galena, sphalerite, marcasite, pyrrhotite, copper sulphides (chalcopyrite, bornite, chalcocite and covellite) and oxides (malachite and azurite) and supergene and hypogene oxidation mineralization zones are different in their paragenesis. Microwave irradiation was performed on a ground sample of ball mill product (flotation feed). Afterwards, by performing flotation experiments, the effect of microwave pre-treatment of ore on the grade and recovery of flotation of sulphide copper, oxide copper and iron were investigated in the feed of Sungun copper processing plant.

\section{Materials and Methods}

\subsection{Introduction of Sungun copper processing circuit and the studied sample}

Sungun copper mine and complex with geographical coordinates $46^{\circ} 43^{\prime} \mathrm{E}$ and $38^{\circ} 42^{\prime} \mathrm{N}$, located in northwestern Iran, is the second largest and most important copper deposit in Iran. This deposit is of porphyry copper-molybdenum type and has more than 750 million tons of sulphide ore with a copper grade of $0.76 \%$ (Alavi et al., 2014). Sulphide minerals in this deposit are pyrite, molybdenite, galena, sphalerite, marcasite, pyrrhotite and copper sulphides mainly include chalcopyrite, bornite, chalcocite and covellite (Alavi et al., 2014). The copper metal of this deposit is mainly formed in chalcopyrite, and to a lesser extent in chalcocite, covellite and bornite mineral. The presence of small amounts of oxide copper in the form of malachite and azurite minerals has also been observed in this deposit (Bahrami et al., 2019a).

The feed of Sungun copper plant, after crushing by gyratory crusher, is ground using semi-autogenous and ball mills to smaller than 150 microns in size, and then the concentration process is performed on it, by flotation method. The processing circuit of this plant is shown in Figure 1. Figure 2 shows a graph of the results of the sieve analysis of the Sungun copper flotation rougher cell feed. According to the results of size analysis, $50 \%$ of feed particles are smaller than 44 microns in size. The $d_{75}$ value for the flotation feed is 100 microns.

In order to investigate the effect of microwave radiation on the flotation process of Sungun copper ore, a sample of ball mill product (shown in red in Figure 1) was prepared, considering the principles of sampling from processing circuits. Sampling was performed in the steady state of the circuit using a sampling spoon. Samples were taken three times with an interval of about 40 minutes and each time 5-8 spoons were sampled. After pressure filtering and drying of the samples, chemical analysis was performed to determine the content elements by the AAS method. According to the results, the feed sample of flotation cells contained $0.69 \%$ of total copper (of which $0.05 \%$ was oxide copper and $0.64 \%$ was sulphide) and $3.89 \%$ iron. According to mineralogical studies, Sungun copper flotation feed consists of metallic, semi-metallic minerals, which are mainly sulphide minerals and rarely semi-metallic oxides, iron hydroxides (goethite) and elemental copper. With a decrease in particle size, the volumetric percentage of metal minerals increased, so that the volumetric percentage of metallic minerals in the size fraction of $+180 \mathrm{mi}-$ 
cron was $0.1-0.3 \%$ and in the fraction of $+45-75$ micron it reached about $10 \%$. Chalcopyrite, as the most abundant copper mineral in this sample, is mainly interlocked with non-metallic gangue minerals and its degree of liberation varies from $35-40 \%$ in the +180 micron size fraction to about $90 \%$ for particles in the size range of $+45-75$ micron (Salehi, 2018). Chalcopyrite has the highest recovery (56.2 wt. \%) corresponding to the flotation with $\mathrm{d}_{80}$ between 80 to 100 micron. The degree of liberation of chalcopyrite, in this case, is about $95 \%$. Chalcopyrite particles with $\mathrm{d}_{80}$ more than 100 microns were recovered at the early stages of the flotation process (Bahrami et al., 2019b).

\subsection{Microwave irradiation}

Bosch HMT72G420 microwave machine with a nominal power of 800 watts and a frequency of $2450 \mathrm{MHz}$ was used to pre-treat the samples. In each experiment, a sample (inside a glass container) was placed inside the device. The treatment tests were performed in three durations of 40, 80 and $120 \mathrm{~s}$ and at powers of 90,360 and $600 \mathrm{~W}$. Totally, 9 microwave radiation experiments were performed according to Table 1.

Table 1: Pre-treatment experiments with microwave device under different duration and intensity of radiation

\begin{tabular}{|l|l|l|}
\hline $\begin{array}{l}\text { Experiment } \\
\text { No. }\end{array}$ & $\begin{array}{l}\text { Microwave } \\
\text { irradiation duration } \\
\text { (s) }\end{array}$ & $\begin{array}{l}\text { Microwave } \\
\text { irradiation power } \\
\text { (W) }\end{array}$ \\
\hline 1 & 40 & 90 \\
\hline 2 & 80 & 90 \\
\hline 3 & 120 & 90 \\
\hline 4 & 40 & 360 \\
\hline 5 & 80 & 360 \\
\hline 6 & 120 & 360 \\
\hline 7 & 40 & 600 \\
\hline 8 & 80 & 600 \\
\hline 9 & 120 & 600 \\
\hline
\end{tabular}

\subsection{Flotation experiments}

Flotation experiments of microwave pre-treated samples were performed using a Denver D12 laboratory flotation device with a rotor speed of $900 \mathrm{rpm}$ for conditioning and $1250 \mathrm{rpm}$ for concentrating in a 2.5-liter cell. Pulp with a $30 \%$ solid (for this purpose $500 \mathrm{~g}$ of solid mixed with $1166 \mathrm{ml}$ water) and a solution whose $\mathrm{pH}$ was adjusted to 11 using sodium hydroxide (caustic soda) was used for testing. Sodium isopropyl xanthate $(15 \mathrm{~g} / \mathrm{t})$ and flomin $(25 \mathrm{~g} / \mathrm{t})$ have also been used as collectors and A70 (Poly propylene glycol - $10 \mathrm{~g} / \mathrm{t}$ ) and A65 (Methyl Isobutyl carbonyl $-5 \mathrm{~g} / \mathrm{t}$ ) as frothers. For flotation experiments, after preparing the pulp and resting for a conditioning time of 3 minutes, the $\mathrm{pH}$ was adjusted and the collector and frother were added to the cell. The condi- tioning time of the collector and the frother is considered 2 minutes and 1 minute, respectively. After that, aeration was started and concentrate was collected at 30, 60, 180 and $300 \mathrm{~s}$. Finally, the feed, concentrate and tailings of the flotation experiments, after dewatering and drying, were analyzed for total $\mathrm{Cu}, \mathrm{CuO}$ and $\mathrm{Fe}$ content with atomic absorption analysis (AAS). It should be mentioned that the above conditions are the same for all flotation experiments.

\section{Results and Discussion \\ 3.1. Effect of microwave radiation on the flotation process of copper minerals}

Figure 3 shows the grade - time and recovery - time diagrams of copper flotation under different irradiation power and times of microwaves. According to the figure, in the case of an irradiation time of 40 seconds, in all times of concentrating, with an increase in power up to 90 watts, the grade increases. With an increase in the radiation power to 360 watts, the grade decreases and then, with an even larger increase in radiation power (600 watts), the grade value increases (at concentrating times of 30 and 60 seconds). During the 80 and $120 \mathrm{sec}-$ ond irradiation times, at all concentrating times and at each irradiation time, the microwave radiation power increases to 360 watts and then decreases. Changes in $\mathrm{Cu}$ recovery in an irradiation time of 40 seconds have a different trend than those at 80 and 120 seconds. During this time of radiation, with an increase in radiation power up to 360 watts, the recovery decreases and then increases significantly. In case of radiation times of 80 and 120 seconds, recovery decreases with a decrease in radiation power. As mentioned, Sungun copper flotation feed consists of copper sulphide minerals, gangue minerals such as pyrite and, to a lesser extent, copper oxide minerals. The floatability of pyrite and chalcopyrite, as the major gangue mineral and the major copper-bearing mineral in Sungun copper ore, respectively, decreases with an increase in time and radiation power (Gholami et al., 2020). Therefore, a decrease in the amount of copper grade as well as the recovery of flotation under the radiation of microwaves can be attributed to the decrease in the floatability of these minerals.

Given that changes in the surface properties of minerals due to microwave radiation are different from each other; in the following, the effect of intensity and time of microwave radiation on the grade and flotation recovery of copper sulphide - oxide minerals as well as iron is investigated.

\subsection{The effect of microwave radiation on the flotation process of copper sulphide minerals}

a) Investigation of the effect of microwave radiation intensity on copper sulphide minerals: Microwave irradiation on the surface of copper sulphide minerals 


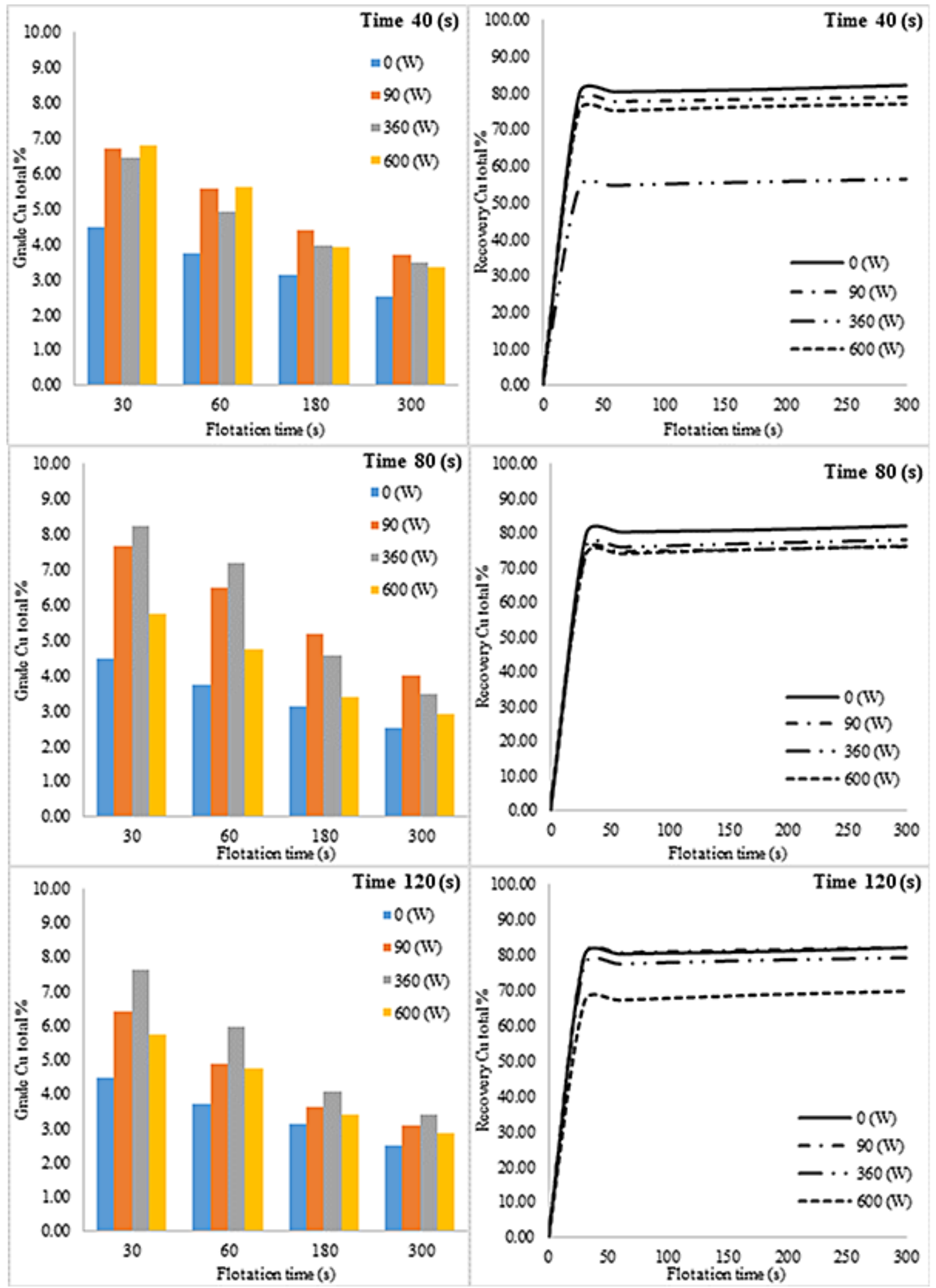

Figure 3: Diagrams of copper grade and recovery - flotation time at 90, 360 and 6oo W microwave radiation power 


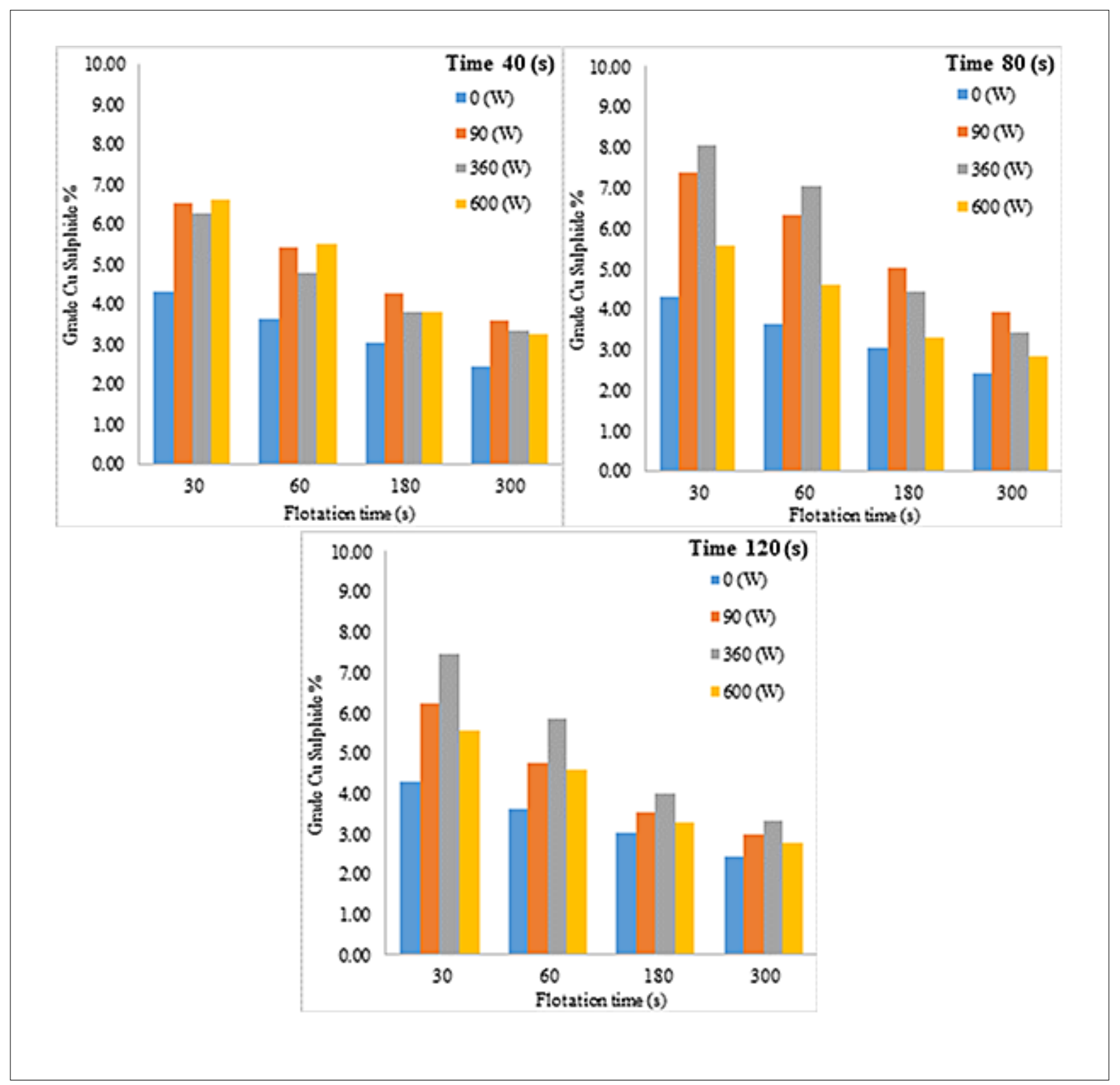

Figure 4: Diagrams of Cu sulphide grade - flotation time at 9o, 360 and 6oo W microwave radiation power

changes their recovery and grade during the flotation process by altering their surface properties (Gholami et al., 2020). Figure 4 shows the diagrams of grade - flotation time of copper sulphides under the power of 90,360 and 600 watts microwave irradiation and the same irradiation time. The results of these diagrams indicate that with an increase in the power of microwave radiation in all times of radiation, the copper sulphide content has increased. During the irradiation times of 40 and 80 seconds, the highest grade value is obtained at 90 watts radiation power and the grade value decreases with an increase in radiation power. Over longer periods of microwave radiation, grade value increases with an increase in radiation power to 360 watts, and then decreases with increasing radiation. The grade improvement may be due to the reduced flotation capacity of gangue minerals, such as pyrite and galena, as well as the presence of metal-deficient sulphides or poly-sulphides on the surface of copper-containing minerals that are formed during the oxidation process (due to microwave irradiation) and increase the collector-less floatability of the mineral (Smart et al., 2003).

Diagrams of the recovery time of copper sulphide mineral flotation affected by microwave radiation are shown in Figure 5. According to the diagrams, in all cases, the maximum recovery value is related to the sample that was not exposed to radiation. With an increase in radiation power, the recovery time is reduced, and this reduction is more noticeable at high microwave radiation power of 360 and 600 watts. As a result of microwave radiation on 


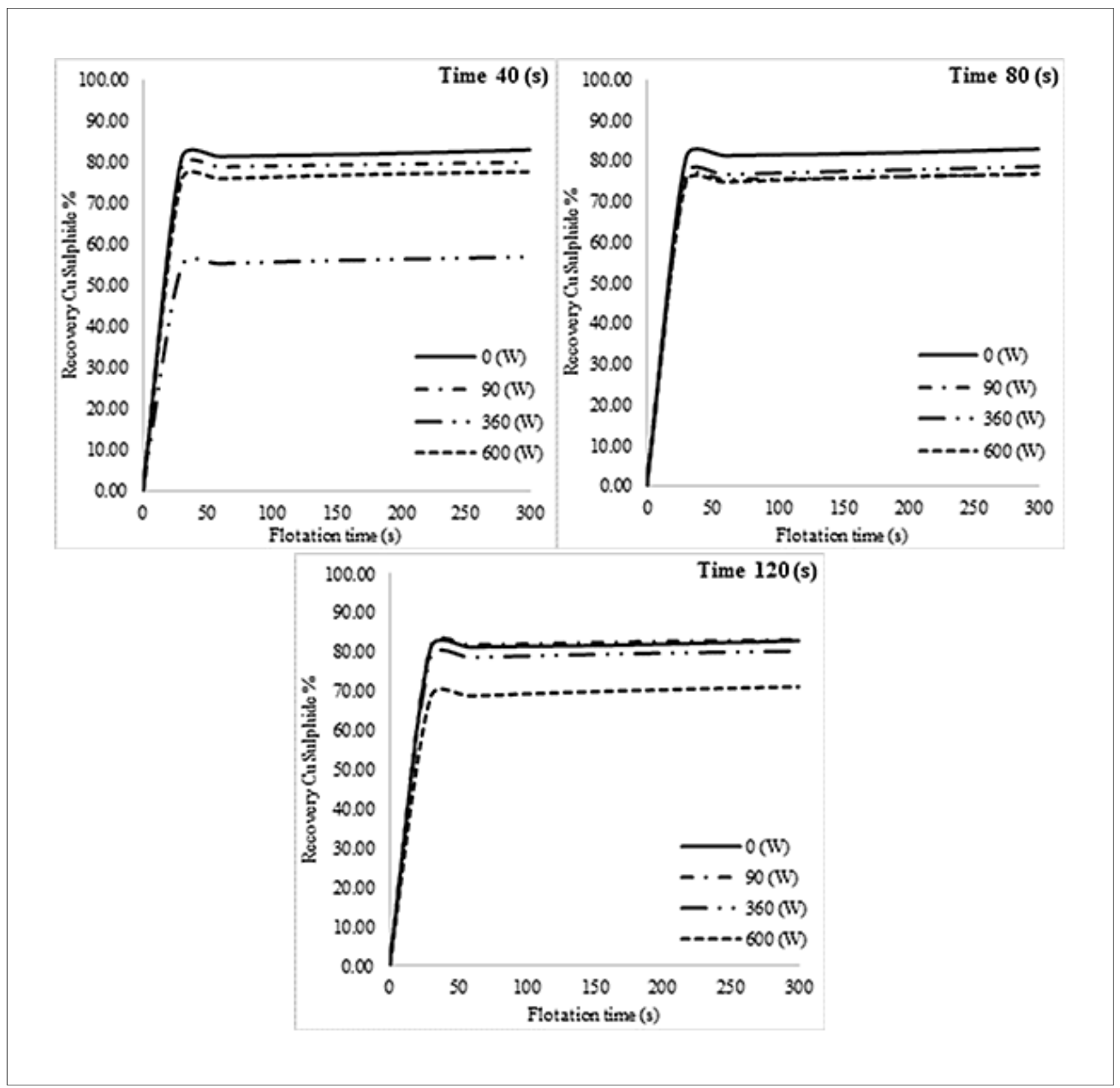

Figure 5: Diagrams of recovery - flotation time Cu sulphides for microwave radiation power of 9o, 360 and 6oo W

chalcopyrite mineral, due to the absorption of wave energy by the mineral and the conversion of this energy in the mineral structure into heat, the mineral surfaces oxidize. Thus, the formation of oxides, hydroxides, and oxyhydroxides at the mineral surface will reduce the grade and recovery value of chalcopyrite (Da-Silva and Waters, 2018; Gholami et al., 2020). On the other hand, due to the fact that the absorption rate of pyrite (as gangue mineral) is similar to chalcopyrite, when exposed to microwaves, this gangue mineral will also behave similarly to chalcopyrite during the flotation process (Gholami et al., 2020). Other copper sulphide minerals in Sungun copper flotation feed (including bornite, chalcocite, and covellite) have lower heat absorption rates than chalcopyrite. Therefore, the floatability of these minerals will be less affected by the microwave (Da-Silva and Waters, 2018; Gholami et al., 2020).

b) Investigation of the effect of microwave radiation time on copper sulphide minerals: Radiation time is an important parameter in determining the floatability of different minerals. The diagrams in Figure 6 show the recovery values of sulphide copper under different times of microwave irradiation and at the same radiation power. At 90 and 360 watts powers, the recovery decreased with an increase in the duration of microwave radiation to 80 seconds, and by increasing it to 120 seconds, the recovery increased. In a study by Da-Silva et al. (2018), it was observed that increasing the exposure time of sulphide minerals to microwave radiation reduces the recovery of chalcopyrite because $\mathrm{CuFeS}_{2}$ is converted to 


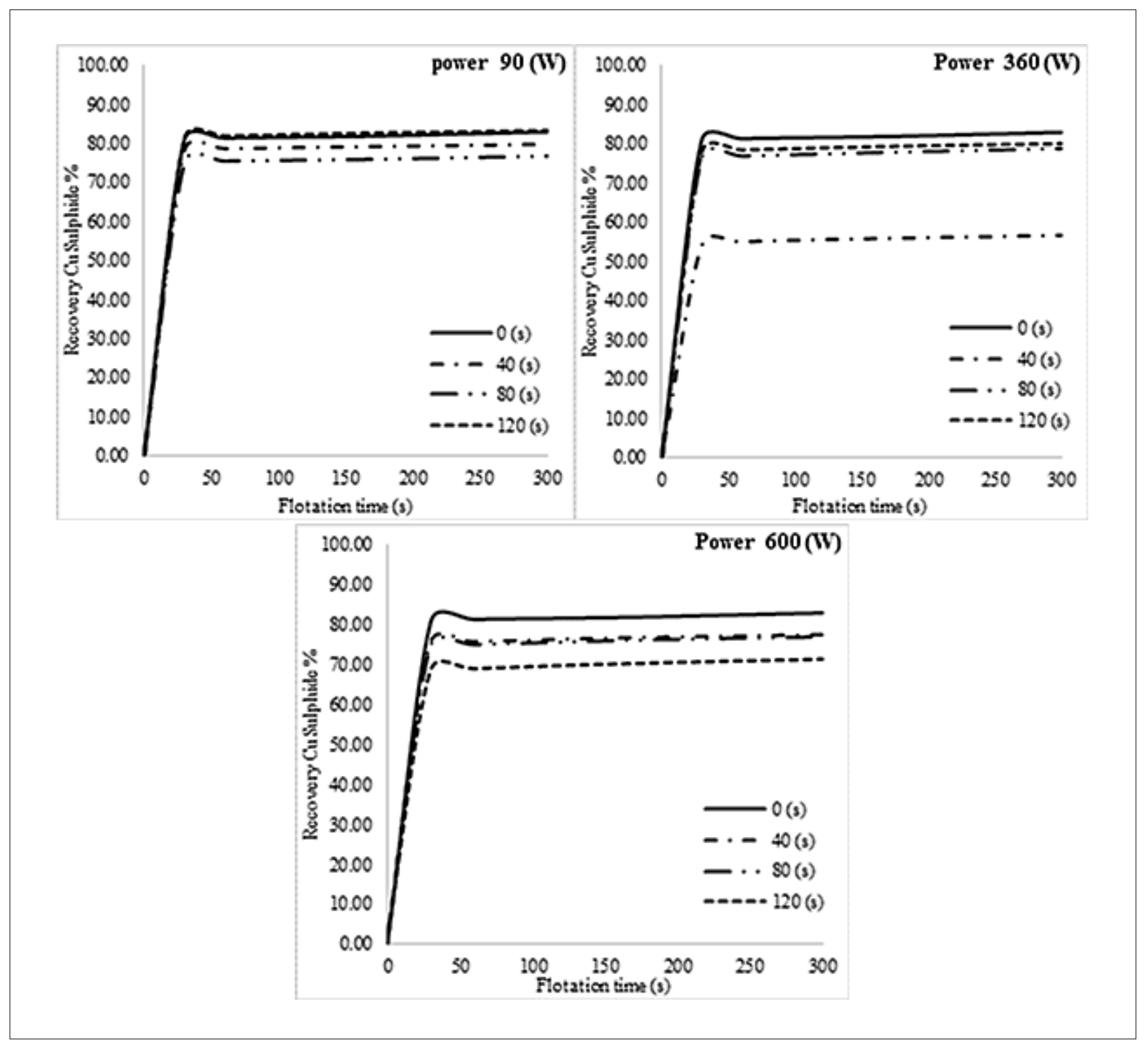

Figure 6: Diagrams of Cu sulphide recovery - flotation time under o, 40, 8o and 120 s of microwave irradiation

iron oxides, hydroxides, oxyhydroxides and sulfates. Also, the surface energy of chalcopyrite increases during prolonged exposure to microwaves.

Examination of the grade values shows (see Figure 7) that with an increase in microwave irradiation time up to 80 seconds (especially at 90 and 360 watts power), the grade value increases but with an increase in the irradiation time up to 120 seconds, the grade value decreases. This is due to the surface oxidation of chalcopyrite mineral by microwave radiation over long periods of radiation. In general, in all radiation powers, the highest grade values are related to the sample that has been exposed to microwave radiation for 80 seconds. Based on EDX analysis of chalcopyrite mineral, microwaving reduces the percentage of copper and increases iron and sulfur in it (Mirshekari et al., 2019). In general, increased oxidation reduces sulfur by creating sulfate $\mathrm{SO}_{4}^{2-}$ on the min- eral surface (EImahdy et al., 2016). In this case, surface sulfur forms porous crystalline layers on the mineral surface (Klauber, 2008).

The study of copper sulphide grade in flotation tailings under different durations and power of microwave radiation is given in Table 2 . The grade of copper sulphide in flotation tailings without a microwave effect is $0.14 \%$. According to the table, with microwave irradiation, the amount of copper sulphide grade has increased in the flotation tailings due to a decrease in the floatability of copper sulphide minerals, especially chalcopyrite.

\subsection{The effect of microwave radiation on the flotation process of copper oxide minerals}

a) Variations in grade and flotation recovery of copper oxide minerals affected by microwave radiation intensity: 


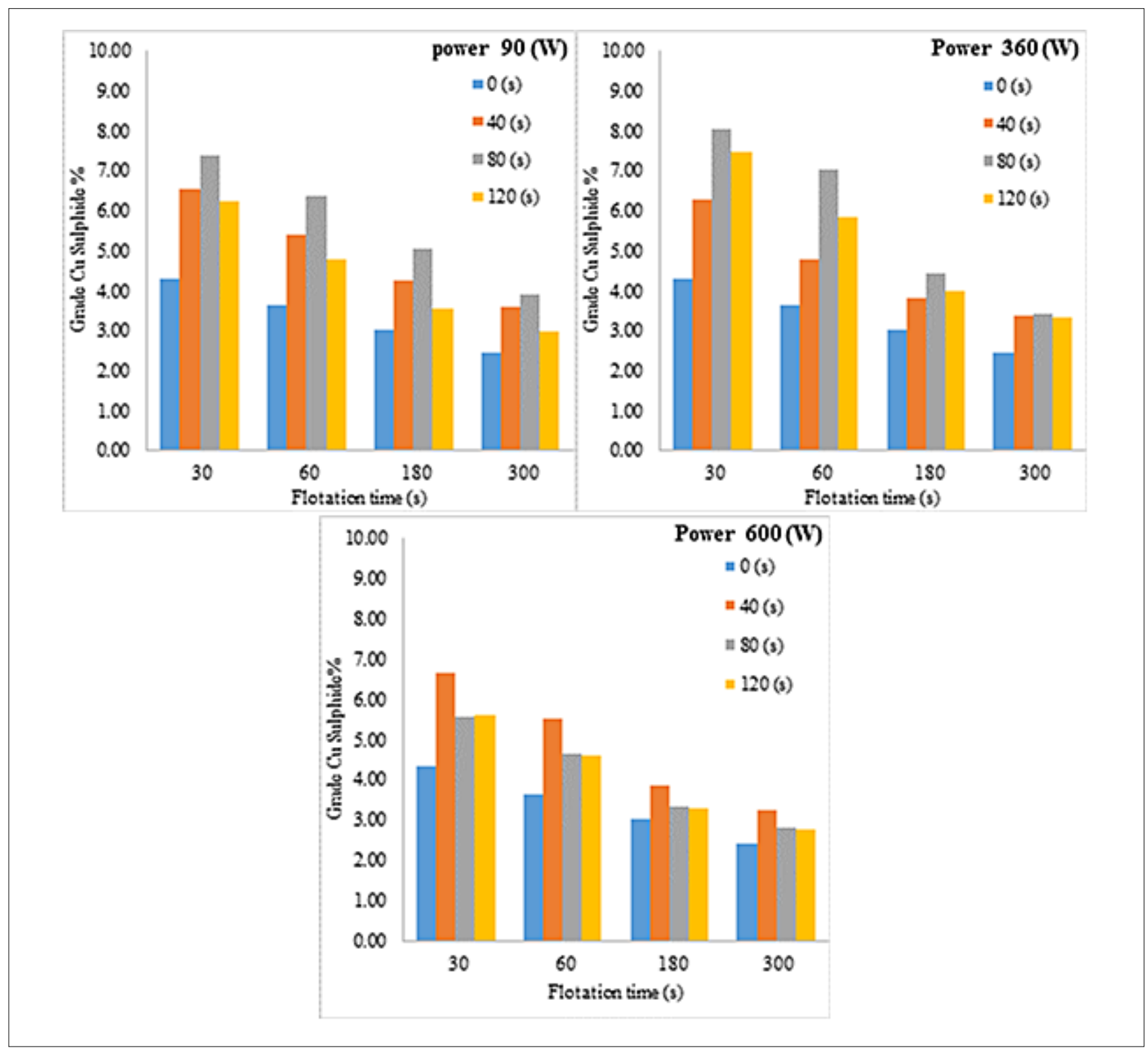

Figure 7: Diagrams of Cu sulphide grade - flotation time under o, 40, 80 and $120 \mathrm{~s}$ of microwave irradiation

Table 2: Variation of copper sulphide grade in flotation tailings under the influence of microwave radiation time and intensity parameters

\begin{tabular}{|l|c|c|c|c|c|c|c|c|c|}
\hline \multirow{2}{*}{$\begin{array}{l}\text { Microwave irradiation } \\
\text { power-time }\end{array}$} & \multicolumn{3}{|c|}{$90(\mathrm{~W})$} & \multicolumn{3}{c|}{$360(\mathrm{~W})$} & \multicolumn{3}{c|}{$600(\mathrm{~W})$} \\
\cline { 2 - 24 } & $40(\mathrm{~s})$ & $80(\mathrm{~s})$ & $120(\mathrm{~s})$ & $40(\mathrm{~s})$ & $80(\mathrm{~s})$ & $120(\mathrm{~s})$ & $40(\mathrm{~s})$ & $80(\mathrm{~s})$ & $120(\mathrm{~s})$ \\
\hline Copper sulphide grade \% & 0.15 & 0.17 & 0.13 & 0.31 & 0.16 & 0.15 & 0.17 & 0.18 \\
\hline
\end{tabular}

Due to the presence of copper oxide minerals along with copper sulphides in the feed of Sungun Copper Processing Plant, the effect of microwave radiation on their flotation has been investigated. Figure 8 shows the diagrams of grade - flotation time for copper oxides under the power of 90,360 and 600 watts microwave radiation at the same intervals. According to the figure, microwave radiation of 90 watts has increased the copper oxide grade during different concentrating times. However, with an increase in microwave radiation power, this increase in grade has de- creased. In general, the highest values for copper oxide grade in flotation concentrate are obtained at a radiation power of 90 watts and a radiation duration of 80 seconds.

The recovery values of copper oxide at different concentrating times and under different microwave radiation power are shown in Figure 9. According to the figure, with an increase in microwave radiation power from 90 to 360 watts, copper oxide recovery has decreased. However, with an increase in power to 600 watts, the recovery has increased in all concentrating times and for two radia- 


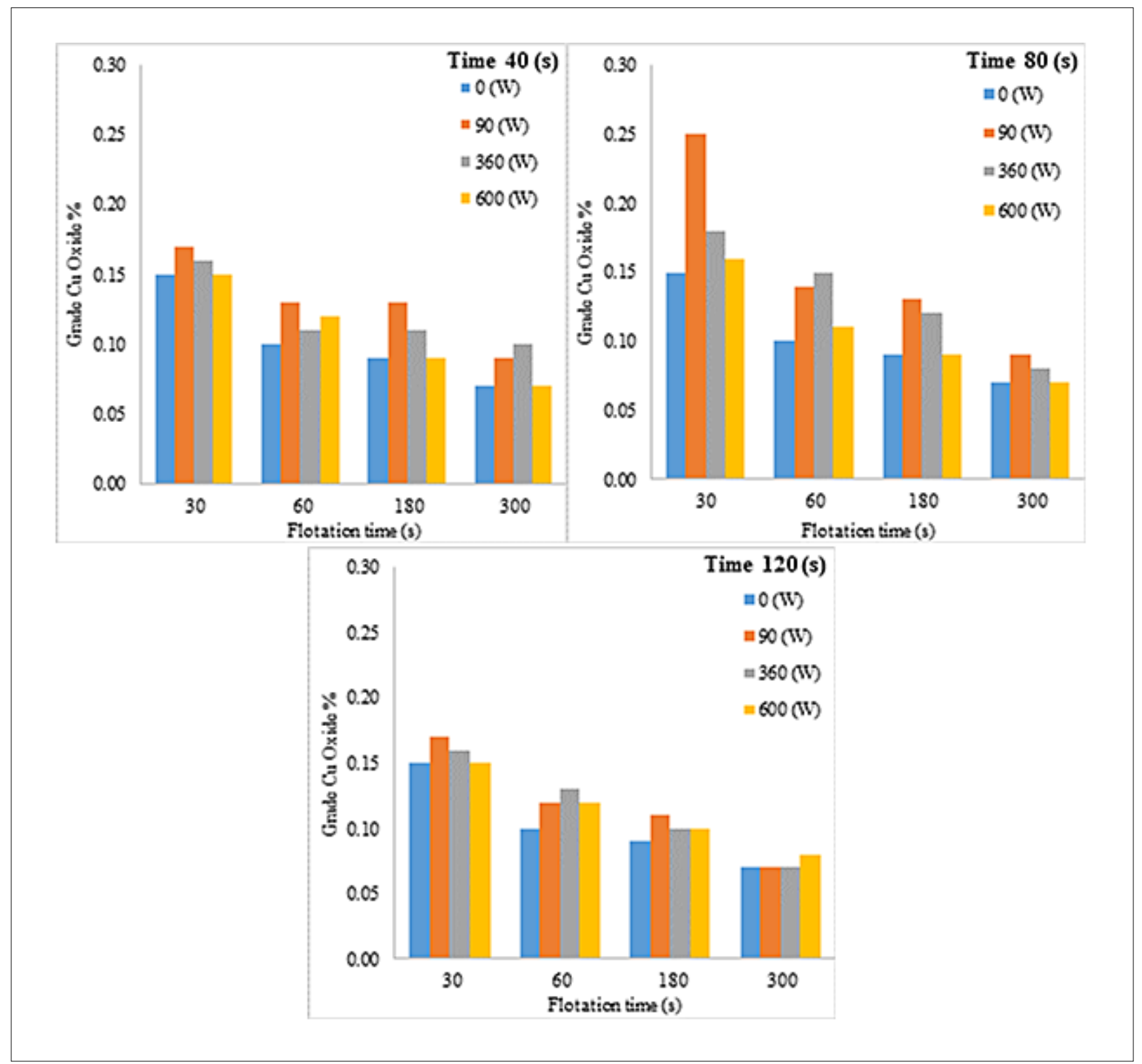

Figure 8: Diagrams of $\mathrm{Cu}$ oxide grade - flotation time at 9o, 360 and $600 \mathrm{~W}$ microwave radiation power

tion periods of 40 and 80 seconds. It is worth mentioning that the decrease in copper oxide recovery values is more noticeable and greater than the decrease in sulphide copper recovery with an increase in radiation power. For example, by increasing the radiation power from 0 to 360 watts over 80 seconds, the reduction of copper sulphide recovery was $7 \%$, while under the same conditions, the recovery of copper oxides decreased by $27 \%$.

b) Variations in grade and flotation recovery of copper oxide minerals affected by microwave radiation time: Investigation of the effect of microwave irradiation time on the surface of copper oxide minerals and their effect on the floatability of minerals is shown in the diagrams (grade and recovery - flotation time) of Figure 10. At powers of 90 and 360 watts of radiation, with an increase in the time of microwave irradiation up to 80 seconds, the grade increased and at a power of 600 watts, the grade decreased (about $0.2 \%$ ). However, at high radiation powers (600 watts), with an increase in the duration of microwave radiation, copper oxide grade increased with a mild trend. In general, the highest values of copper oxide grade are obtained at a radiation power of 90 watts and a radiation duration of 80 seconds.

According to the diagrams of recovery - flotation time, at powers of 90 and 360 watts, increasing the irradiation time to 80 seconds reduces the recovery, and then, as the irradiation time increases, the recovery time increases. While at 600 watts of irradiation power, increasing the duration of microwave exposure to 80 seconds did not have a significant effect on recovery. However, increasing the irradiation time to 120 seconds has led to a sharp decline in the recovery of copper oxide minerals. 


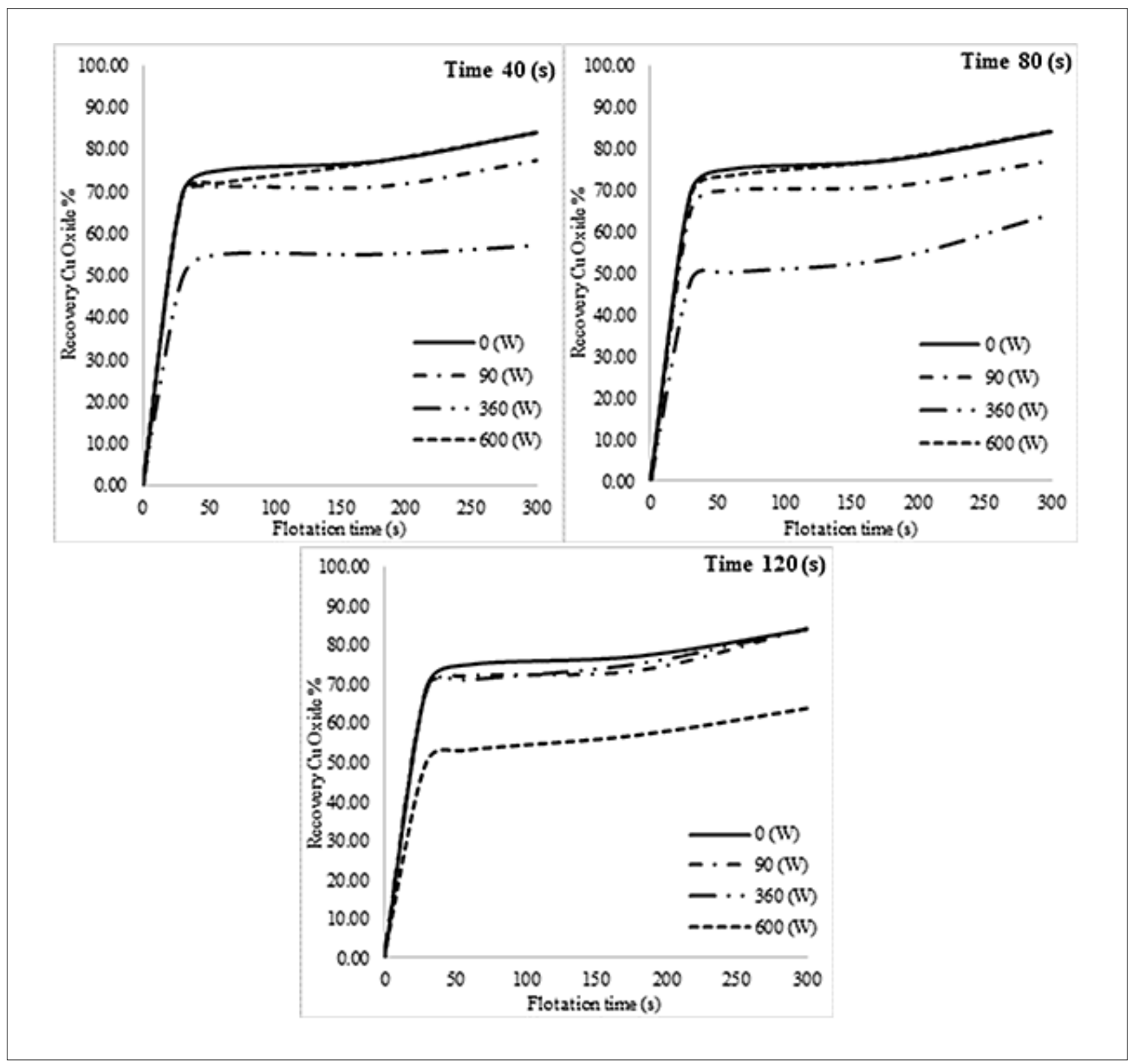

Figure 9: Diagrams of $\mathrm{Cu}$ oxide recovery - flotation time at 90, 36o and 6oo W microwave radiation power

Study of copper oxide grade values in flotation tailings under different times and power of microwave irradiation (see Table 3 ) indicates that the variations of copper oxide in flotation tailings have not changed significantly. Copper oxide grade of flotation tailings is $0.02 \%$ and the microwave radiation at different powers and times has not changed this amount.

\subsection{The effect of microwave radiation on grade changes and the rate of introduction of iron-bearing minerals in copper flotation concentrate}

a) Investigation of the effect of microwaves irradiation power on iron-bearing minerals: Considering that Fe grade, as a contaminating element, in copper flotation concentrate due to the presence of chalcopyrite $\left(\mathrm{CuFeS}_{2}\right)$ and pyrite $\left(\mathrm{FeS}_{2}\right)$ minerals, as well as iron oxide-hydroxides, such as hematite and goethite, it can be said that microwave irradiation on a flotation feed has an influence on changes of Fe grade and recovery to the copper concentrate. Figure 11 shows the grade-time diagrams of concentrate for iron. According to Figure 11, changes in iron grade due to irradiation intensity have a different trend than copper sulfide and oxide minerals. With an increase in microwave radiation power from 90 to 360 watts, the iron grade (in the early times of concentrating) has increased by about $4 \%$. It is worth mentioning that increasing the power of microwave radiation increases the surface oxidation and leads to the formation of magnetic phases such as goethite $(\mathrm{FeOOH})$ and hematite $\left(\mathrm{Fe}_{2} \mathrm{O}_{3}\right)$ on the surface of chalcopyrite and pyrite miner- 


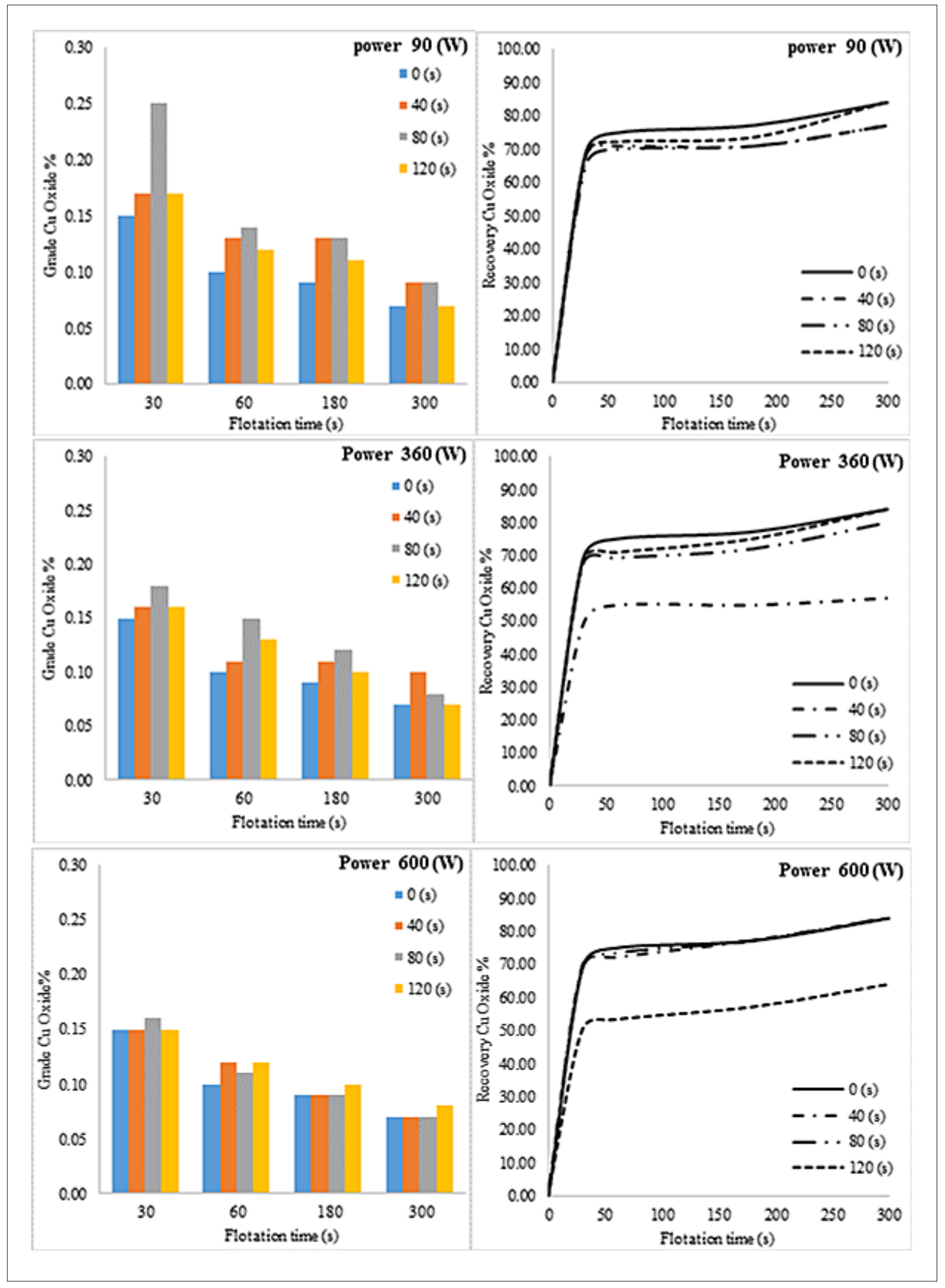

Figure 10: Diagrams of grade and recovery of $\mathrm{Cu}$ oxide - flotation time under o, 40, 8o and 120 s of microwave irradiation 
Table 3: Copper oxide grade in flotation tailings under the influence of microwave radiation time and intensity parameters

\begin{tabular}{|l|l|l|l|l|l|l|l|l|l|}
\hline \multirow{2}{*}{$\begin{array}{l}\text { Microwave irradiation } \\
\text { power - time }\end{array}$} & \multicolumn{3}{|c|}{$90(\mathrm{~W})$} & \multicolumn{3}{c|}{$360(\mathrm{~W})$} & \multicolumn{3}{c|}{$600(\mathrm{~W})$} \\
\cline { 2 - 11 } & $40(\mathrm{~s})$ & $80(\mathrm{~s})$ & $120(\mathrm{~s})$ & $40(\mathrm{~s})$ & $80(\mathrm{~s})$ & $120(\mathrm{~s})$ & $40(\mathrm{~s})$ & $80(\mathrm{~s})$ & $120(\mathrm{~s})$ \\
\hline Copper oxide grade \% & 0.02 & 0.02 & 0.02 & 0.03 & 0.02 & 0.02 & 0.02 & 0.02 & 0.03 \\
\hline
\end{tabular}

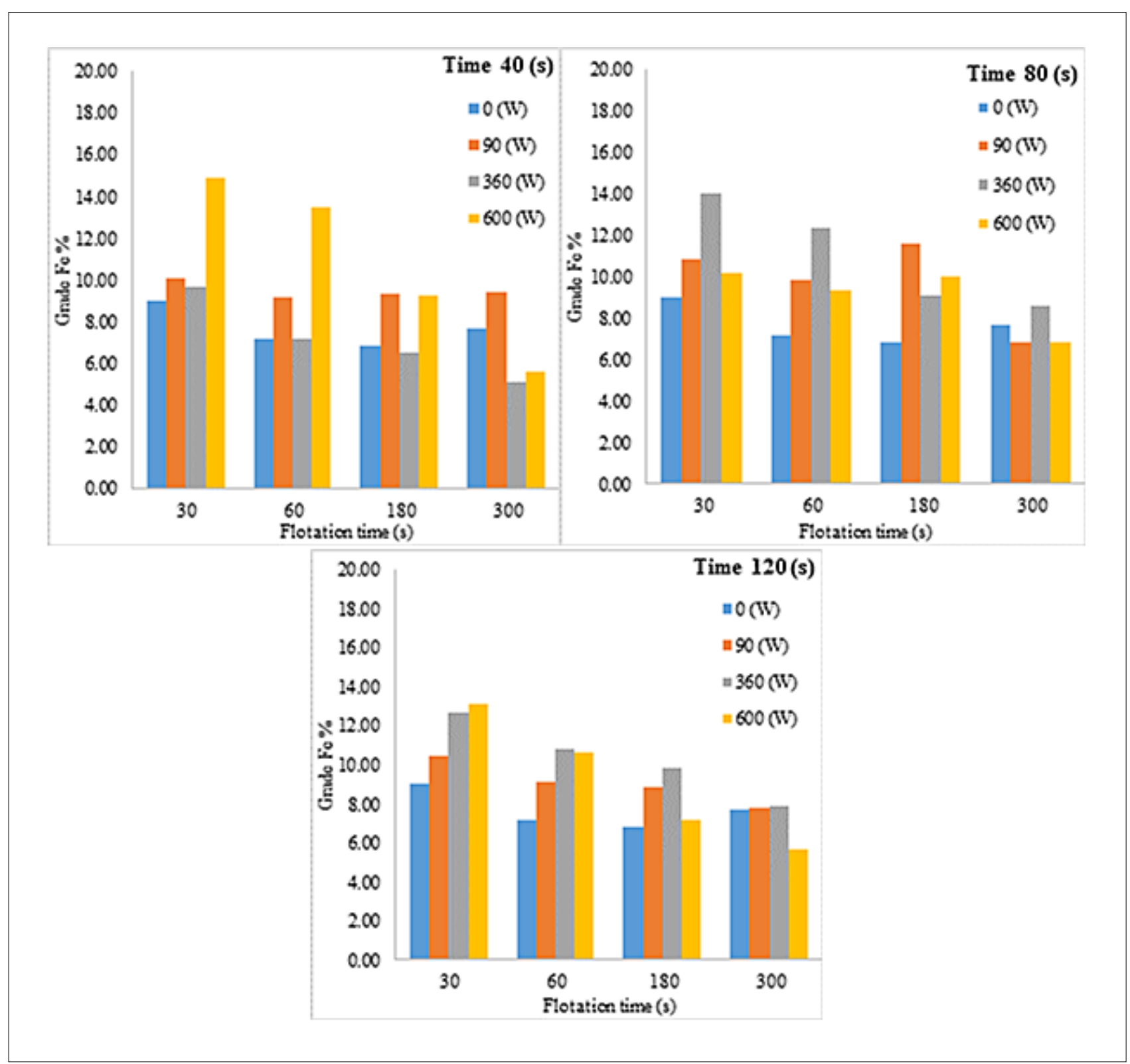

Figure 11: Diagrams of iron grade - flotation time at 90, 360 and 6oo W microwave irradiation power

als. This mechanism increases the magnetic properties of chalcopyrite and pyrite (this mechanism is created with changes in orientation of electrons of atoms in surface of minerals) (Gholami et al., 2020). From the point of view of increasing the iron content in copper concentrate, we can say that microwave radiation on a copper flotation feed is inappropriate.

Changes in the percentage of iron in the copper concentrate affected by different powers of microwave radiation are shown in Figure 12. Maximum recovery val- ues are related to the sample that has not been irradiated and with an increase in microwave radiation power, the recovery value has decreased. The decrease in iron introduction rate to the concentrate is more noticeable at a power of 360 watts of radiation, and with an increase in irradiation time, it has occurred more and more. As mentioned, the high heat generated by the absorption of microwaves causes a reaction between the minerals in the ore and their chemical change. Due to the absorption of these waves and chemical changes, the amount of iron in 


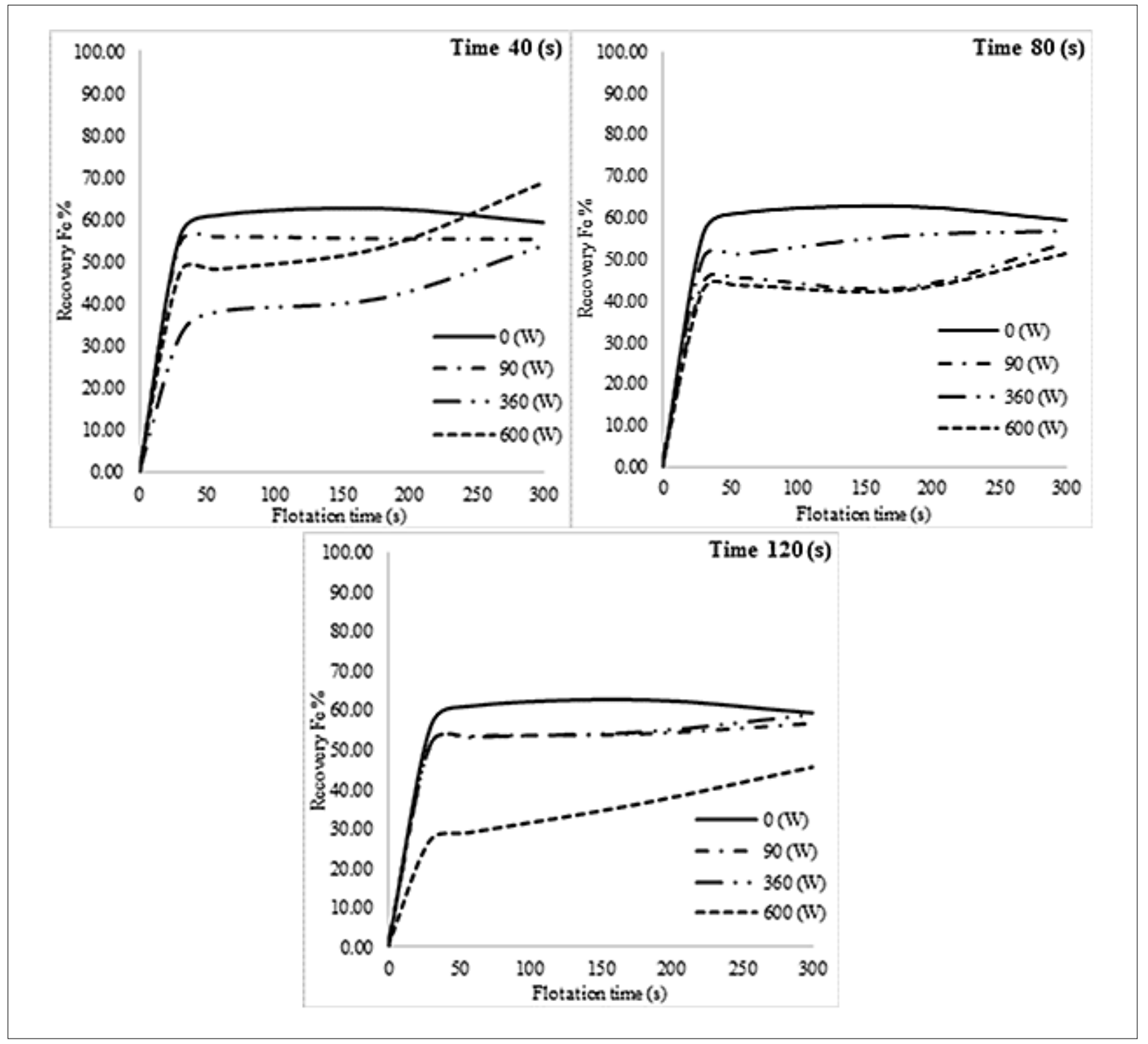

Figure 12: Diagrams of Iron recovery - flotation time in copper concentrate under 90, 360 and 6oo W microwave irradiation power

the surface of pyrite and chalcopyrite is reduced due to the formation of iron oxide sulfate $\left(\mathrm{Fe}_{2}\left(\mathrm{SO}_{4}\right)_{3}\right)$ (Elmahdy et al., 2016), which can be attributed to the reasons for the decrease in the amount of iron in the copper concentrate.

b) Investigation of the effect of microwaves irradiation time on iron-bearing minerals: Diagrams of iron grade and recovery - flotation time, at different times of microwave irradiation are shown in Figure 13. According to the figure, at different powers of irradiation, as the duration of microwave irradiation increases, the trend of iron grade changes has been different. The highest values of iron grade are obtained at all times of microwave radiation at 360 watts. In all cases, the amount of iron recovered from the copper concentrate decreased with an increase in microwave irradiation time. The largest drop in recovery was related to 600 watts of radiation power. In this power of microwave radiation, the recovery values have decreased significantly with an increase in the duration of radiation.

\section{Conclusions}

In this study, the grade and recovery changes of flotation of copper ore treated by microwave irradiation method are investigated. In this regard, due to the presence of copper oxide minerals as well as the presence of iron, changes in the recovery of copper sulphide, copper oxide and iron in flotation concentrate were investigated. According to the results, in all samples treated by microwave at different times and powers, the total copper grade as well as the iron improved after irradiation, 


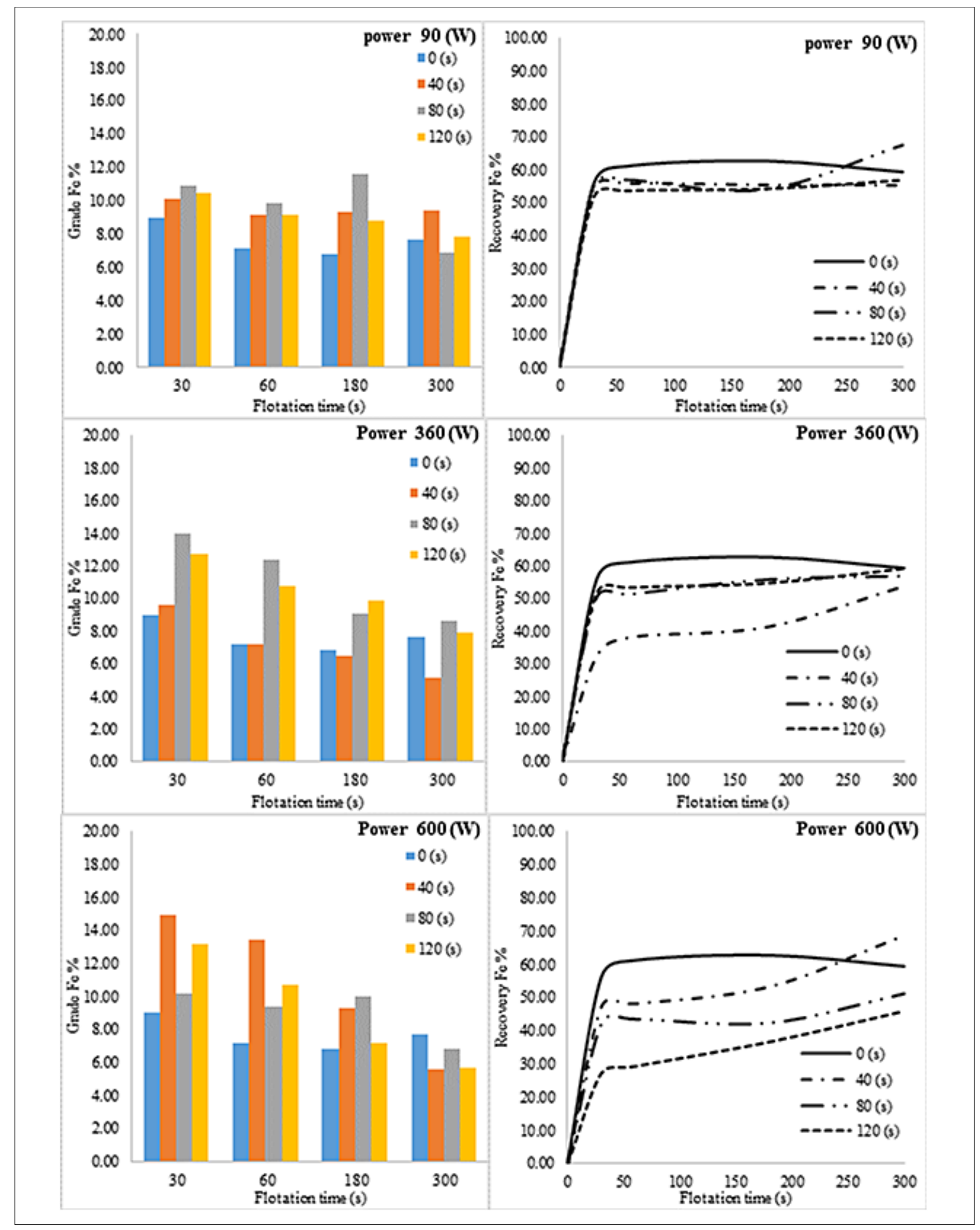

Figure 13: Diagrams of iron recovery and grade - flotation time under o, 40, 8o and $120 \mathrm{~s}$ of microwave radiation

but the recovery decreased, which is important from the point of view of reducing the introduction of iron to the copper concentrate. At low radiation powers, as irradia- tion time increases, the total copper recovery is reduced with a gentle slope. However, at higher powers, the recovery is greatly reduced by increasing the irradiation 
time to 120 seconds. The effect of increasing the irradiation power of microwaves on increasing the iron content was greater than the effect of irradiation time. Also, the comparison of changes in sulphide and oxide copper recovery due to changes in the duration and power of microwave radiation indicates that the power of radiation had a greater effect on reducing the recovery of oxide copper. However, the reduction in sulphide copper recovery was more affected by changes in irradiation time.

\section{Conflict of interest}

On behalf of all authors, the corresponding author (Sajjad Chehreghani) states that there is no conflict of interest.

\section{References}

Abdollahi, M. (2019): The Effect of texture and mineralogy on flotation recovery of molybdenite at the Sungun copper complex/concentrator plant. Master of Science Thesis in Mining Engineering, Urmia University (in Persian).

Alavi, S.G., Hossein zadeh, M., Moaeid, M. (2014): Petrography and petrology of the Sungun porphyry copper deposit and post mineralization dykes with a view to Skarn mineralization (north of Varzeghan, East Azerbaijan). Journal of Petrology, 17, 5, 17-32. (In Persian).

Bahrami, A., Ghorbani, Y., Abdollahi Sharif, J., Kazemi, F., Abdollahi, M., Salahshur, A., Danesh, A. (2019a): A geometallurgical study of flotation performance in supergene and hypogene zones of Sungun copper deposit. Journal of Mineral Processing and Extractive Metallurgy, 130, 2, 126-135. https://doi.org/10.1080/25726641.2019.1591794.

Bahrami, A., Mirmohammadi, M., Ghorbani, Y., Kazemi, F., Abdollahi, M., Danesh, A. (2019b): Process mineralogy as a key factor affecting the flotation kinetics of copper sulfide minerals. International Journal of Minerals, Metallurgy, and Materials, 26, 4, 430-439. https://doi.org/ 10.1007/s12613-019-1733-9.

Batchelor, A.R., Buttress, A.J., Jones, D.A., Katrib, J., Way, D., Chenje, T., Stoll, D., Dodds, C., Kingman, S.W. (2017): Towards large scale microwave treatment of ores: Part 2Metallurgical testing. Journal of Minerals Engineering, 111, 5-24. https://doi.org/10.1016/j.mineng.2017.05.003.

Batchelor, A.R., Jones, D.A., Plint, S., Kingman, S.W. (2016): Increasing the grind size for effective liberation and flotation of a porphyry copper ore by microwave treatment. Journal of Minerals Engineering, 94, 61-75. https://doi. org/10.1016/j.mineng.2016.05.011.

Marion, C., Jordens, A., Maloney, C., Langlois, R., Waters, K.E. (2016): Effect of microwave radiation on the processing of a $\mathrm{Cu}-\mathrm{Ni}$ sulphide ore. Journal of Chemical Engineering, 94, 117-127. https://doi.org/10.1002/cjce.22359.

Da-Silva, G.R., Waters, K.E. (2018): The effects of microwave irradiation on the floatability of chalcopyrite, pentlandite and pyrrhotite. Jornal of Advanced Powder Technology, 29, 12, 3049-3061. https://doi.org/10.1016/j.apt.2018.07.025.

Elmahdy, A.M., Farahat, M., Hirajima, T. (2016): Comparison between the effect of microwave irradiation and conven- tional heat treatments on the magnetic properties of chalcopyrite and pyrite. Journal of Advanced Powder Technology, 27, 6, 2424-2431. https://doi.org/10.1016/j.apt.2016. 08.020 .

Da-Silva, G.R., Espiritu, E.R.L., Mohammadi-Jam, S., Waters, K.E. (2018): Surface characterization of microwavetreated chalcopyrite, Journal of Colloids Surface - A Physicochemical Engineering Aspects, 555, 407-417. https:// doi.org/10.1016/j.colsurfa.2018.06.078.

Gholami, H., Rezaei, B., Mehdilo, A., Hassanzadeh, A., Yarahmadi, M. (2020): Effect of microwave system location on floatability of chalcopyrite and pyrite in a copper ore processing circuit. Journal of Physicochemical Problems of Mineral Processing, 56, 3, 432-448. http://dx.doi.org/ $10.37190 / \mathrm{ppmp} / 118799$

Gholami, H., Rezaei, B., Hassanzadeh, A., Mehdilo, A., Yarahmadi, M., Rudolph, M. (2019a): A kinetic study on grinding and flotation of untreated and microwave-treated copper sulfide ore. IMPC Eurasia Conference, 129-141. 31 October-2 November, Antalya, Turkey.

Gholami, H., Rezaei, B., Hassanzadeh, A., Mehdilo, A., Yarahmadi, M., Rudolph, M. (2019b): Impact of microwave treatment's location on floatability of chalcopyrite and pyrite: a case study of Sarcheshmeh copper complex ore. XVIII Balkan Mineral Processing Congress, 155-165, 2326 May, Durres, Albania.

Hassanzadeh, A. (2017): The effect of make-up ball size regime on grinding efficiency of full-scale ball mill. XVII Balkan Mineral Processing Congress (BMPC) 117-123, 1-3 November, Antalya, Turkey.

Quast, K. (2012): Effect of $25 \%$ goethite on the hydrophobicity and oleate flotation of hematite. Doctoral dissertation, Scientific \& Academic Publishing.

Quast, K. (2016): Surface chemistry and oleate flotation of three South Australian micaceous hematites. Journal of Minerals Engineering, 85, 123-129. https://doi.org/10. 1016/j.mineng.2015.11.002.

Kaya, E. (2010): Effect of microwave radiation on the floatation of copper sulfide ores. Asian Journal of Chemistry, 22, 10, 7874-7882.

Kingman, S.W., Vorster, W., Rowson, N.A. (2000): The effect of microwave radiation on the processing of Palabora copper ore. The Journal of the South African Institute of Mining and Metallurgy, 100, 3, 197-204.

Kingman, S.W., Jackson, K., Bradshaw, S.M., Rowson, N.A., Greenwood, R. (2004): An investigation into the influence of microwave treatment on mineral ore comminution. Journal of Powder Technology, 146, 3, 176-184. https:// doi.org/10.1016/j.powtec.2004.08.006.

Klauber, C. (2008): A critical review of the surface chemistry of acidic ferric sulphate dissolution of chalcopyrite with regards to hindered dissolution. International Journal of Mineral Processing, 86, 1-4, 1-17. https://doi.org/10.1016/j. minpro.2007.09.003.

Mirshekari, B., Kolini, M.G., Shahbazi, B. (2019): The Effect of Microwave Radiation on Flotation of Copper Sulfide Minerals. Journal of separation science and engineering, 1, 11, 1-12. (In Persian). 
Can, N.M., Bayraktar, I. (2007): Effect of microwave treatment on the flotation and magnetic separation properties of pyrite, chalcopyrite, galena and sphalerite. Journal of Minerals and Metallurgical Process, 24, 185-192. https://doi. org/10.1007/BF03403214.

Orumwense, A., Negeri, T. (2004): Impact of microwave irradiation on the processing of a sulfide ore. Journal of Minerals and Metallurgical Process, 21, 44-51. https://doi. org/10.1007/BF03403302.

Henda, R., Hermas, A., Gedye, R., Islam, M.R. (2005): Microwave enhanced recovery of nickel-copper ore: commination and floatability aspects. J. Microw. Journal of Power Electromagnet Energy, 40, 7-16. https://doi.org/10.1080/0 8327823.2005.11688522.

Smart, R.S., Amarantidis, J., Skinner, W.M., Prestidge, C.A., La Vanier, L., Grano, S.R. (2003): Surface analytical stud- ies of oxidation and collector adsorption in sulfide mineral flotation. In Solid-Liquid Interfaces: Macroscopic Phenomena - Macroscopic Understanding, Springer, Berlin, Heidelberg. https://doi.org/10.1007/3-540-44817-9_1.

Joseph-Soly, S., Quast, K., Connor, J.N. (2015): Effects of Eh and $\mathrm{pH}$ on the oleate flotation of iron oxides. Journal of Minerals Engineering, 83, 97-104. https://doi. org/10.1016/j.mineng.2015.08.014.

Salehi, M. (2018): Investigation of the effect of size on flotation operations of Sungun copper complex. BSc thesis, Urmia University. (In Persian).

Worster, W., Rowson, N., Kingman, S. (2001): The effect of microwave radiation upon the processing of Neves Corvo copper ore. International Journal of Mineral Processing, 63, 1, 29-44. https://doi.org/10.1016/S0301-7516(00)00069-7.

\section{SAŽETAK}

\section{Učinak mikrovalnoga ozračivanja na flotabilnost mješavine ruda sulfida i oksida bakra}

Predobradba ruda bakrenoga sulfida i oksida uporabom mikrovalnoga ozračivanja uzrokuje razliku u njihovoj flotabilnosti zbog promjene površinskih svojstava minerala. Istraženo je ponašanje bakrene rude iz porfirita Sunguna nakon takva ozračivanja. Uzorak iz navedenoga rudnika bio je izložen mikrovalnomu procesu tijekom o - 120 sekundi, uz zračenje snage o - $600 \mathrm{~W}$. Zatim su uzroci podvrgnuti flotaciji. Nakon toga je koncentracija minerala bakrenih sulfida i oksida, ali i željeza, bila povećana. Nasuprot tomu pridobivanje je opadalo u svim slučajevima. Promjene u iznosima pridobivanja oksida i sulfida bakra zbog ozračivanja bile su različite. Povećanje snage rezultiralo je većom redukcijom pridobivanja oksida nego sulfida, ali je reduciralo i iznos željeza u koncentratu bakra, i to usporedno s vremenom ozračivanja. Promjene snage i vremena mikrovalnoga ozračivanja nisu imale znatnoga utjecaja u koncentraciji oksida bakra u preostalome materijalu nakon flotacije. Međutim koncentracija sulfida bakra ovisila je o tome procesu i bila je korelativna s vremenom i snagom ozračivanja.

\section{Ključne riječi:}

mikrovalovi, flotacija, bakreni oksidi i sulfidi, željezo, predobradba

\section{Author's contribution}

Ataallah Bahrami (Associate Professor, Minerals Processing) proposed the idea and guided the research. Sajad Chehreghani (Assistant Professor, Minerals Processing) proposed the idea and guided the research. Fatemeh Kazemi (PhD student of mineral processing) performed tests, provided reports, and wrote the article. Hamid Kazemi (MSc student of mineral processing) performed tests, analyses and provided reports. Abdollah Forughirad (MSc student of mineral processing) provided a medical analysis and presented the results. Behnam Golizadeh (MSc student of mineral processing) performed tests, analyses and provided reports. 